\title{
EVALUATION OF ANTIPROLIFERATIVE ACTIVITY OF PYRAZOLOTHIAZOLOPYRIMIDINE DERIVATIVES
}

\author{
N. S. FINIUK ${ }^{1,2}$, Yu. V. OSTAPIUK ${ }^{2}$, V. P. HRENIUKH ${ }^{2}$, Ya. R. SHALAI', \\ V. S. MATIYCHUK ${ }^{2}$, M. D. OBUSHAK ${ }^{2}$, R. S. STOIKA ${ }^{1 *}$, A. M. BABSKY ${ }^{2 * *}$ \\ ${ }^{1}$ Institute of Cell Biology, National Academy of Sciences of Ukraine, Lviv; \\ ${ }^{2}$ Ivan Franko National University of Lviv, Ukraine; \\ *e-mail: stoika@cellbiol.lviv.ua; **e-mail: andriy.babsky@lnu.edu.ua
}

\begin{abstract}
The research aim was to test cytotoxic effects in vitro of seven novel pyrazolothiazolopyrimidine derivatives in targeting several lines of tumor and pseudo-normal mammalian cells. We demonstrated that cytotoxic effects of these derivatives depended on the tissue origin of targeted cells. Leukemia cells were found to be the most sensitive to the action of compounds $\mathbf{2}$ and 7 . Compound $\mathbf{2}$ demonstrated approximately two times higher toxicity towards the multidrug-resistant sub-line of HL-60/ADR cells compared to the Doxorubicin effect. Antiproliferative action of compounds $\mathbf{2}$ and $\mathbf{7}$ dropped in the order: leukemia $>$ melanoma $>$ hepatocarcinoma $>$ glioblastoma $>$ colon carcinoma $>$ breast and ovarian carcinoma cells. These compounds were less toxic than Doxorubicin towards the non-tumor cells. The novel pyrazolothiazolopyrimidine, compound 2, demonstrated high toxicity towards human leukemia and, of special importance, towards multidrug-resistant leukemia cells, and low toxicity towards pseudo-normal cells.
\end{abstract}

Keywords: pyrazolothiazolopyrimidines, Doxorubicin, antiproliferative activity in vitro.

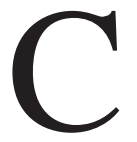

hemotherapy is commonly used for cancer treatment or palliation. However, the chemotherapeutic agents may influence not only tumor but also normal cells, and thus, possess low specificity and/or selectivity [1]. Drug resistance is another major problem of the chemotherapy. Therefore, new drugs should be developed that avoid the above noted problems in their action.

We have addressed the heterocycles, the active pharmacophores, as potential anticancer agents $[2,3]$. Pyrazolopyridine-based derivatives exhibit pharmacological properties $[4,5]$, as well as antiviral [6], anticonvulsant [7], antileishmanial [8], and antimicrobial (e. g. anti-tuberculostatic) activities [4]. Khobragade et al. reported that pyrazolo[3,4-d] thiazolo[3,2-a]pyrimidin-4-one derivatives possess xanthine oxidase inhibitory activity. This enzyme catalyzes the conversion of hypoxanthine to xanthine and then the conversion of xanthine to uric acid [9]. The pyrazolo[4,3-e][1,2,4]triazolo[1,5-c]pyrimidines were found to have adenosine receptor antagonistic activity, and were studied as new drugs for asthma, Parkinson's disease or inflammation treatment
$[10,11]$. Some pyrazoles inhibit a tissue-nonspecific alkaline phosphatase that is important for normal bone mineralization [12].

These derivatives also possess antitumor properties [2, 13-19]. The fluorinated pyrazolo [3,4-d] pyrimidine derivatives containing 1,3,4-thiadiazole exhibit toxicity against human myeloid leukemia HL-60 cells [12]. The 1,2,3-triazole tagged pyrazolo[3,4-b]pyridines were active towards leukemia cell lines (HL-60, U937) and less active towards melanoma B16-F10 cells [15]. Kandeel et al. reported that thieno[3,2-e]-1,2,4-triazolo[4,3-c]pyrimidines demonstrated cytotoxic activity towards leukemia and central nervous system tumor cells [16]. The hydrazine, oxadiazole, thiadiazole and 1,2,4-triazole functionalized pyrazolo[3,4-b]pyridines [17], spiro[pyrazolo[4,3-d]pyrimidinones [19] showed growth inhibition of leukemia cells, breast and colon carcinoma, lung and cervical tumor cells. Shamroukh et al. detected that specific pyrazole and pyrazolo[3,4-d]pyrimidine derivatives exhibit prominent cytotoxic activity towards breast adenocarcinoma MCF-7 and hepatocarcinoma HepG2 cell

(C) 2018 Finiuk N. S. et al. This is an open-access article distributed under the terms of the Creative Commons Attribution License, which permits unrestricted use, distribution, and reproduction in any medium, provided the original author and source are credited. 
lines by inhibiting the expression of urokinase plasminogen activator [18]. Pyrazolo[3,4-d]pyrimidines with a 4-(1H-benzimidazol-2-yl)-phenylamine side chain demonstrated toxicity towards leukemia, glioblastoma and melanoma cells [14].

Thus, pyrazolothiazolopyrimidine derivatives are attractive heterocycles for pharmaceutical and medicinal chemists who design new potent anticancer agents $[14,20]$.

Doxorubicin is a chemotherapeutic anthracycline drug commonly used to treat different types of cancer, such as breast, ovarian tumors, bladder cancer, lymphomas, leukemia, and others. Doxorubicin intercalates into the DNA molecule and inhibits its biosynthesis. Doxorubicin induces the apoptosis via AMP-activated protein kinase (AMPK), Bcl-2/ Bax, p53 pathways and caspases activation [21-23]. Doxorubicin can also affect the production of free radicals [21]. It should be noted that Doxorubicin is not a specifically targeting drug [21, 24]. Dilated cardiomyopathy is the most dangerous side effect of Doxorubicin [21-23].

The aim of our study was to test the cytotoxic effects in vitro of seven novel pyrazolothiazolopyrimidine derivatives that target several mammalian tumor cell lines and for comparison, pseudo-normal cell lines.

\section{Materials and Methods}

Compounds. A series of seven novel substituted 8-methyl-2-R-7-[R'-phenilmethyl]pyrazolo[4,3-e] $[1,3]$ thiazolo[3,2-a]pyrimidin-4(2H)-ones was synthesized at the Chemistry Faculty of Ivan Franko National University of Lviv, Ukraine: compound $1-\mathrm{R}=\mathrm{Me}, \mathrm{R}^{\prime}=4-\mathrm{Me} ; 2-\mathrm{R}=\mathrm{Me}, \mathrm{R}^{\prime}=3-\mathrm{CF} 3$; $3-\mathrm{R}=\mathrm{Me}, \mathrm{R}^{\prime}=\mathrm{H} ; \mathbf{4}-\mathrm{R}=\mathrm{Me}, \mathrm{R}^{\prime}=4-\mathrm{F} ; \mathbf{5}-\mathrm{R}=\mathrm{Pr}$, $\mathrm{R}^{\prime}=3-\mathrm{CF} 3 ; \mathbf{6}-\mathrm{R}=\operatorname{Pr}, \mathrm{R}^{\prime}=4-\mathrm{F} ; \mathbf{7}-\mathrm{R}=\operatorname{Pr}, \mathrm{R}^{\prime}=\mathrm{H}$.

The stock solution of tested compounds $(10 \mathrm{mM})$ was prepared in dimethyl sulfoxide (DMSO, Sigma-Aldrich, St. Louis, MO, USA), and before adding to the cells, further solutions were prepared using culture medium [25]. Doxorubicin (Dox, Teva, Haarlem, the Netherlands) was used as a positive control.

Cell culture. Human myeloid leukemia HL-60 and the multidrug resistant sub-line of human myeloid leukemia HL-60/ADR cells (MRP1 over-expression), human myeloid leukemia K-562 cells, human hepatocarcinoma HepG2 cells, and human colon carcinoma HCT116 cells were from a collection of the Institute of Cancer Research at
Vienna Medical University (Vienna, Austria). Human ovarian carcinoma SKOV3 cells were from the American Type Culture Collection (ATCC, Manassas, VA, USA) and were donated by Dr. O. Stasyk (Institute of Cell Biology, National Academy of Sciences of Ukraine, Lviv, Ukraine). Human glioblastoma U-251 MG cells, human HaCaT keratinocytes and murine monocyte macrophage J774.2 cells were from a collection at the Institute of Molecular Biology and Genetics, National Academy of Sciences of Ukraine (Kyiv, Ukraine). Human breast adenocarcinoma MCF-7 cells, human melanoma SK-MEL-28 cells and human embryonic kidney cells of HEK293 line were from Cell Collection of R.E. Kavetsky Institute of Experimental Pathology, Oncology and Radiobiology (Kyiv, Ukraine). Cells were grown in RPMI-1640 (APP, Vienna, Austria) or Dulbecco's modified Eagle's medium (DMEM, Sigma-Aldrich, St. Louis, MO, USA) culture medium supplemented with $10 \%$ fetal bovine serum (APP, Vienna, Austria). Cells were cultivated at $37^{\circ} \mathrm{C}$ in an atmosphere of $5 \% \mathrm{CO}_{2}$.

MTT assay for cell proliferation. The antineoplastic activity of the synthesized compounds and Doxorubicin towards cell lines of different tissue origin was examined using the MTT (Sigma-Aldrich, St. Louis, MO, USA) test. Briefly, cells were seeded overnight into 96-well plates in $100 \mu \mathrm{l}$ at concentrations of 5,000 cells/well (substrate-dependent cells) or 10,000 cells/well (suspension cells). Aliquots of $100 \mu \mathrm{l}$ of experimental compounds $(0-50 \mu \mathrm{M})$ were added to culture medium and cells were incubated for the next $72 \mathrm{~h}$. The $72 \mathrm{~h}$ term of compound exposure was used in order to analyze the possible cytotoxic activity of studied compounds without time-related limitation. The MTT (3-(4,5-dimethyl thiazol-2-yl)-2,5-diphenyl tetrazolium bromide) was added to the cells, as described previously [26]. The results of the reaction were determined by an Absorbance Reader BioTek ELx800 (BioTek Instruments, Inc., Winooski, VT, USA). The $\mathrm{IC}_{50}$ of tested compounds was calculated as the drug concentration that reduced cell viability to $50 \%$.

Data analysis. The results were analyzed and illustrated using GraphPad Prism 6 software (GraphPad Software, La Jolla, CA, USA). All data are presented as the mean \pm standard deviation (SD) of three replications in two parallels $(n=6)$. A t test and the column statistics of GraphPad Prism 6 software were used for statistical analysis. Statistical significance was identified at $P \leq 0.05$. 


\section{Results and Discussion}

The anti-proliferative activities of seven novel pyrazolothiazolopyrimidine derivatives were evaluated in human tumor cell lines of different tissue origin (leukemia (K-562, HL-60, HL-60/ADR), melanoma (SK-MEL-28), glioblastoma (U-251 MG), colon (HCT116), hepatocyte (HepG2), ovary (SKOV3) and breast (MCF-7)) and towards non-tumor cells (HEK293, HaCaT and J774.2) using the MTT test in order to identify if the cytotoxicity of the pyrazolothiazolopyrimidine derivatives is tissue dependent. Doxorubicin that is widely used for treatment of solid tumors [27, 28] was used as a positive control. The anticancer activity of the tested compounds was expressed as the $\mathrm{IC}_{50}$ value.

Our data showed that leukemia cells were the most sensitive to the action of pyrazolothiazolopyrimidine derivatives. All tested compounds inhibited human myeloid leukemia K-562 cells proliferation to a different extent. Compounds $\mathbf{2}$ and $\mathbf{7}$ demonstrated the highest effect in cell viability inhibition $\left(\mathrm{IC}_{50}\right.$ was 3.0 and $3.1 \mu \mathrm{M}$, respectively, Fig. 1, Table). The $\mathrm{IC}_{50}$ value for compound 3 was $5.7 \mu \mathrm{M}$; for 5 was $8.8 \mu \mathrm{M}$; and for $\mathbf{4}$ was $10.4 \mu \mathrm{M}$. Compounds 6 and $\mathbf{1}$ possessed the least pronounced toxicity for K-562 cells ( $\mathrm{IC}_{50}$ of 21.1 and $43.8 \mu \mathrm{M}$, respectively, Fig. 1, Table). Doxorubicin was less toxic for K-562 cells ( $\mathrm{IC}_{50}$ was $10.2 \mu \mathrm{M})$.

These data showed that all compounds possess similar anti-proliferative activity towards human myelogenic leukemia HL-60 cells, compared with the action of Doxorubicin. The cytotoxic action of pyrazolothiazolopyrimidines and Doxorubicin towards HL-60 cells (Fig. 1, Table) was as follows: Doxorubicin $\left(\mathrm{IC}_{50}=0.090 \mu \mathrm{M}\right)=$ compound $2\left(\mathrm{IC}_{50}=0.090 \mu \mathrm{M}\right)>7\left(\mathrm{IC}_{50}=0.096 \mu \mathrm{M}\right)>\mathbf{3}$
$\left(\mathrm{IC}_{50}=0.104 \mu \mathrm{M}\right)>\mathbf{6}\left(\mathrm{IC}_{50}=0.131 \mu \mathrm{M}\right)>\mathbf{4}$
$\left(\mathrm{IC}_{50}=0.172 \mu \mathrm{M}\right) \approx \mathbf{1}\left(\mathrm{IC}_{50}=0.174 \mu \mathrm{M}\right)>\mathbf{5}$
$\left(\mathrm{IC}_{50}=0.550 \mu \mathrm{M}\right)$.
Rapid development of multidrug resistance is one of the main problems in leukemia treatment. The mechanisms of such resistance can be associated with the over-expression of the $\mathrm{ABC}$ transporters (e.g. multidrug resistance gene 1 [MDR1], such as P-glycoprotein and multidrug resistance protein 1 [MRP1]) [29]. Here, we have studied the anti-neoplastic activity of the pyrazolothiazolopyrimidine derivatives towards human myeloid leukemia HL-60/ADR cells (a multidrug resistant sub-line that over-expresses MRP1) [29]. We found that compound 2 possessed the highest cytotoxic action towards HL-60/ADR cells $\left(\mathrm{IC}_{50}=3.9 \mu \mathrm{M}\right)$, and such effect was more prominent than the effect of Doxorubicin $\left(\mathrm{IC}_{50}=8.9 \mu \mathrm{M}\right)$ (Table). Compound 7 showed a lesser growth inhibition effect on the HL-60/ADR cells $\left(\mathrm{IC}_{50}=11.2 \mu \mathrm{M}\right)$. Compounds $\mathbf{6}$ and $\mathbf{5}$ were also capable of inhibiting cell proliferation of HL-60/ ADR cells $\left(\mathrm{IC}_{50}=45.8\right.$ and $46.1 \mu \mathrm{M}$, respectively). Compounds 1, 3 and $\mathbf{4}$ were poorly toxic towards HL-60/ADR cells in a dose up to $50 \mu \mathrm{M}$ and inhibited cells growth by $28.7,36.9$ and $42.6 \%$, respectively (Fig. 1).

Compounds 2 and 7 inhibited growth of melanoma SK-MEL-28 cells $\left(\mathrm{IC}_{50}=7.2 \mu \mathrm{M}\right.$ and $8.2 \mu \mathrm{M}$, respectively; Fig. 2, Table). Doxorubicin demonstrated approximately 10 times higher toxicity towards melanoma cells $\left(\mathrm{IC}_{50}=0.7 \mu \mathrm{M}\right)$. Compounds $\mathbf{1}, \mathbf{3}, \mathbf{4}$, 5, 6 showed a weak toxic effect for melanoma SKMEL-28 cells and did not reach the $\mathrm{IC}_{50}$ at $50 \mu \mathrm{M}$.

Compounds 7, 2, 3, 5 and $\mathbf{6}$ inhibited the viability of human glioblastoma cells at high concentrations $\left(\mathrm{IC}_{50}=21.5-46.6 \mu \mathrm{M}\right.$, Fig. 2, Table). Doxo-

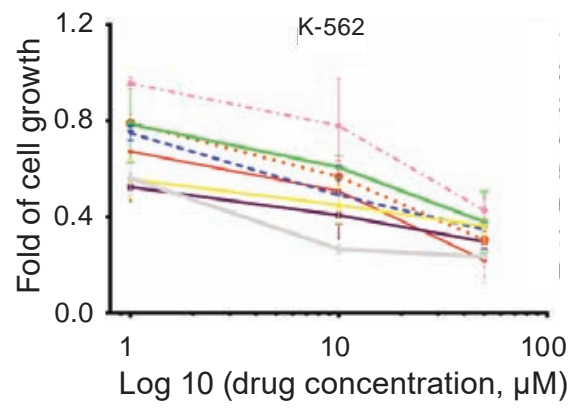

$-1-2-3$
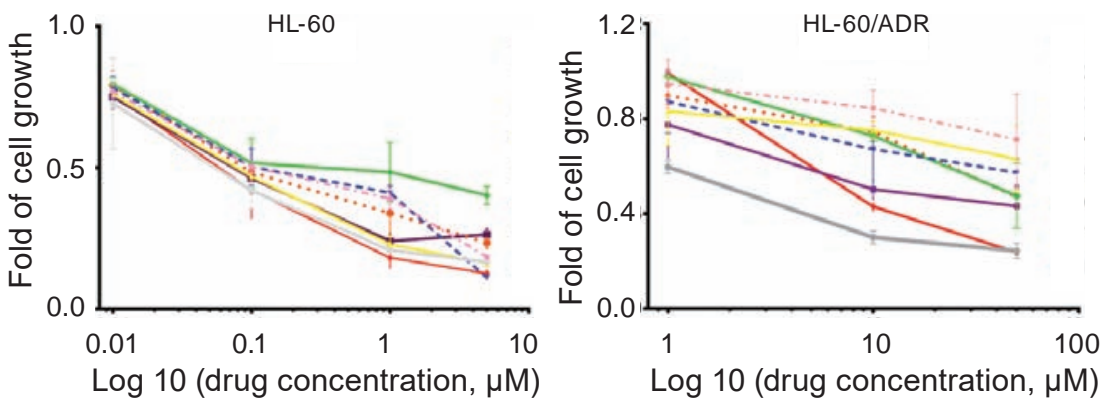

$\begin{array}{lllll}-4 & -5 & \bullet & -7 & -7\end{array}$

Fig. 1. The results of measuring the antiproliferative activity of seven pyrazolothiazolopyrimidines and Doxorubicin (Dox) towards human leukemia cell lines (K-562, HL-60, HL-60/ADR). Cell viability was examined using the MTT assay after $72 \mathrm{~h}$ of the compound exposure. Dox was used as a positive control 
Ta b l e. Cytotoxicity indicator $\left(I_{50}\right)$ of seven pyrazolothiazolopyrimidines and doxorubicin (Dox) in targeting cells of different tissue origin noted in Materials and Methods (72 h, MTT assay)

\begin{tabular}{|c|c|c|c|c|c|c|c|c|}
\hline \multirow{2}{*}{ Cell line } & \multicolumn{8}{|c|}{$\mathrm{IC}_{50}, \mu \mathrm{M}$} \\
\hline & 1 & 2 & 3 & 4 & 5 & 6 & 7 & Dox \\
\hline K-562 & $\begin{array}{c}43.80 \pm \\
0.25\end{array}$ & $\begin{array}{c}3.00 \pm \\
0.09\end{array}$ & $\begin{array}{c}5.70 \pm \\
0.15\end{array}$ & $\begin{array}{r}10.40 \\
\pm 0.13 \\
\end{array}$ & $\begin{array}{c}8.80 \pm \\
0.18\end{array}$ & $\begin{array}{c}21.10 \pm \\
0.21\end{array}$ & $\begin{array}{c}3.10 \pm \\
0.13\end{array}$ & $\begin{array}{c}10.2 \pm \\
0.3\end{array}$ \\
\hline HL-60 & $\begin{array}{c}0.17 \pm \\
0.02\end{array}$ & $\begin{array}{c}0.09 \pm \\
0.01\end{array}$ & $\begin{array}{c}0.10 \pm \\
0.01\end{array}$ & $\begin{array}{c}0.17 \pm \\
0.02\end{array}$ & $\begin{array}{c}0.55 \pm \\
0.05\end{array}$ & $0.13 \pm 0.02$ & $0.1 \pm 0.01$ & $\begin{array}{c}0.09 \pm \\
0.01\end{array}$ \\
\hline HL-60/ADR & $>50$ & $\begin{array}{c}3.90 \pm \\
0.27\end{array}$ & $>50$ & $>50$ & $\begin{array}{l}46.10 \\
\pm 4.19\end{array}$ & $\begin{array}{c}45.80 \pm \\
3.64\end{array}$ & $\begin{array}{c}11.20 \pm \\
0.97\end{array}$ & $\begin{array}{c}8.90 \pm \\
0.65\end{array}$ \\
\hline U-251 MG & $>50$ & $\begin{array}{c}31.90 \pm \\
2.22\end{array}$ & $\begin{array}{c}38.6 \pm \\
2.3\end{array}$ & $>50$ & $\begin{array}{c}46.2 \pm \\
2.89\end{array}$ & $\begin{array}{c}46.60 \pm \\
3.95\end{array}$ & $\begin{array}{c}21.5 \pm \\
1.93\end{array}$ & $\begin{array}{c}21.90 \pm \\
1.67\end{array}$ \\
\hline HCT116 & $>50$ & $\begin{array}{c}32.40 \\
\pm 2.87 \\
\end{array}$ & $\begin{array}{c}42.5 \pm \\
3.62\end{array}$ & $>50$ & $\begin{array}{c}45.4 \pm \\
4.39\end{array}$ & $>50$ & $\begin{array}{c}40.0 \pm \\
4.20\end{array}$ & $\begin{array}{c}1.10 \pm \\
0.09\end{array}$ \\
\hline SK-MEL-28 & $>50$ & $\begin{array}{c}7.20 \pm \\
0.57\end{array}$ & $>50$ & $>50$ & $>50$ & $>50$ & $\begin{array}{l}8.2 \pm \\
0.93\end{array}$ & $\begin{array}{c}0.70 \pm \\
0.06\end{array}$ \\
\hline HepG2 & $>50$ & $\begin{array}{l}25.20 \\
\pm 1.47 \\
\end{array}$ & $>50$ & $>50$ & $>50$ & $>50$ & $\begin{array}{c}26.4 \pm \\
2.24\end{array}$ & $\begin{array}{c}0.90 \pm \\
0.08\end{array}$ \\
\hline MCF-7 & $>50$ & $>50$ & $>50$ & $>50$ & $>50$ & $>50$ & $>50$ & $\begin{array}{c}1.38 \pm \\
0.12\end{array}$ \\
\hline SKOV3 & $>50$ & $>50$ & $>50$ & $>50$ & $>50$ & $>50$ & $>50$ & $\begin{array}{c}2.60 \pm \\
0.22\end{array}$ \\
\hline HEK 293 & $\begin{array}{c}10.60 \pm \\
0.98\end{array}$ & $\begin{array}{c}30.00 \\
\pm 2.88 \\
\end{array}$ & $\begin{array}{r}34.6 \\
\pm 3.7 \\
\end{array}$ & $\begin{array}{l}25.60 \\
\pm 2.18 \\
\end{array}$ & $\begin{array}{r}26.30 \\
\pm 2.82 \\
\end{array}$ & $\begin{array}{c}23.20 \pm \\
2.19\end{array}$ & $\begin{array}{r}33.20 \\
\pm 3.27\end{array}$ & $5.1 \pm 0.6$ \\
\hline HaCaT & $\begin{array}{c}16.30 \pm \\
0.15\end{array}$ & $\begin{array}{c}17.40 \pm \\
0.15\end{array}$ & $\begin{array}{r}21.80 \\
\pm 0.22 \\
\end{array}$ & $\begin{array}{c}17.20 \pm \\
0.19\end{array}$ & $\begin{array}{r}13.60 \\
\pm 0.15 \\
\end{array}$ & $\begin{array}{c}12.70 \pm \\
0.11\end{array}$ & $\begin{array}{r}29.50 \\
\pm 0.31 \\
\end{array}$ & $\begin{array}{c}1.70 \pm \\
0.15\end{array}$ \\
\hline J774. 2 & $14.7 \pm 1.5$ & $\begin{array}{c}20.8 \pm \\
2.1\end{array}$ & $\begin{array}{c}21.3 \pm \\
1.9\end{array}$ & $\begin{array}{c}22.5 \pm \\
2.0\end{array}$ & $\begin{array}{c}20.3 \pm \\
2.2\end{array}$ & $17.2 \pm 1.9$ & $\begin{array}{c}22.7 \pm \\
2.2\end{array}$ & $\begin{array}{c}2.28 \pm \\
0.20\end{array}$ \\
\hline
\end{tabular}

rubicin inhibited glioblastoma cells with an $\mathrm{IC}_{50}$ of $21.9 \mu \mathrm{M}$, while compounds $\mathbf{1}, \mathbf{4}$ did not reach the $\mathrm{IC}_{50}$ at a dose as high as $50 \mu \mathrm{M}$.

Some of the pyrazolothiazolopyrimidine derivatives demonstrated weak toxicity towards human colon carcinoma HCT116 cells. The $\mathrm{IC}_{50}$ value for HCT116 cells was $32.4 \mu \mathrm{M}$ for compound 2; $40.0 \mu \mathrm{M}$ for 7 ; $42.5 \mu \mathrm{M}$ for 3 ; and $45.4 \mu \mathrm{M}$ for 5 (Fig. 2, Table). At the highest dose of $50 \mu \mathrm{M}$, compound 1 inhibited the growth of HCT116 cells by $45 \%$, compound 4 by $47 \%$, and compound 6 by $48 \%$. Doxorubicin was the most toxic compound for HCT116 cells $\left(\mathrm{IC}_{50}=1.1 \mu \mathrm{M}\right)$.

Cytotoxic activity of compounds 2 and 7 towards human hepatocyte carcinoma HepG2 cells was observed at their high concentrations $\left(\mathrm{IC}_{50}=25.2\right.$ and $26.4 \mu \mathrm{M}$, respectively; Fig. 2, Table). Doxorubicin was the most toxic when acting towards HepG2 cells ( $\mathrm{IC}_{50}$ was $\left.0.9 \mu \mathrm{M}\right)$. Compounds 1, 3, 4, 5 and 6 did not reach the $\mathrm{IC}_{50}$ value even at a $50 \mu \mathrm{M}$ dose. The inhibition of growth of HepG2 cells equaled in the range of $38.5-46.0 \%$ at the action of compounds 4, 1, 3, 5 and 6 .

Human breast adenocarcinoma MCF-7 cells and human ovarian carcinoma SKOV3 cells demonstrated the weakest sensitivity to the action of the pyrazolothiazolopyrimidines. None of tested compounds had an $\mathrm{IC}_{50}$ value at $50 \mu \mathrm{M}$ (Fig. 2, Table). We observed the maximum of $32.1 \%$ growth inhibition of MCF-7 cells under the effect of compound 2 and minimum of $10 \%$ under the effect of compounds 4 and 6 (Fig. 2). Similar toxicities of the pyrazolothiazolopyrimidines were found for SKOV3 cells: $27.2 \%$ of growth inhibition under the effect of compound $\mathbf{7}$ and $7.2 \%$ for the action of compound $\mathbf{6}$ (Fig. 2). Measurement of the $\mathrm{IC}_{50}$ for Doxorubicin in 

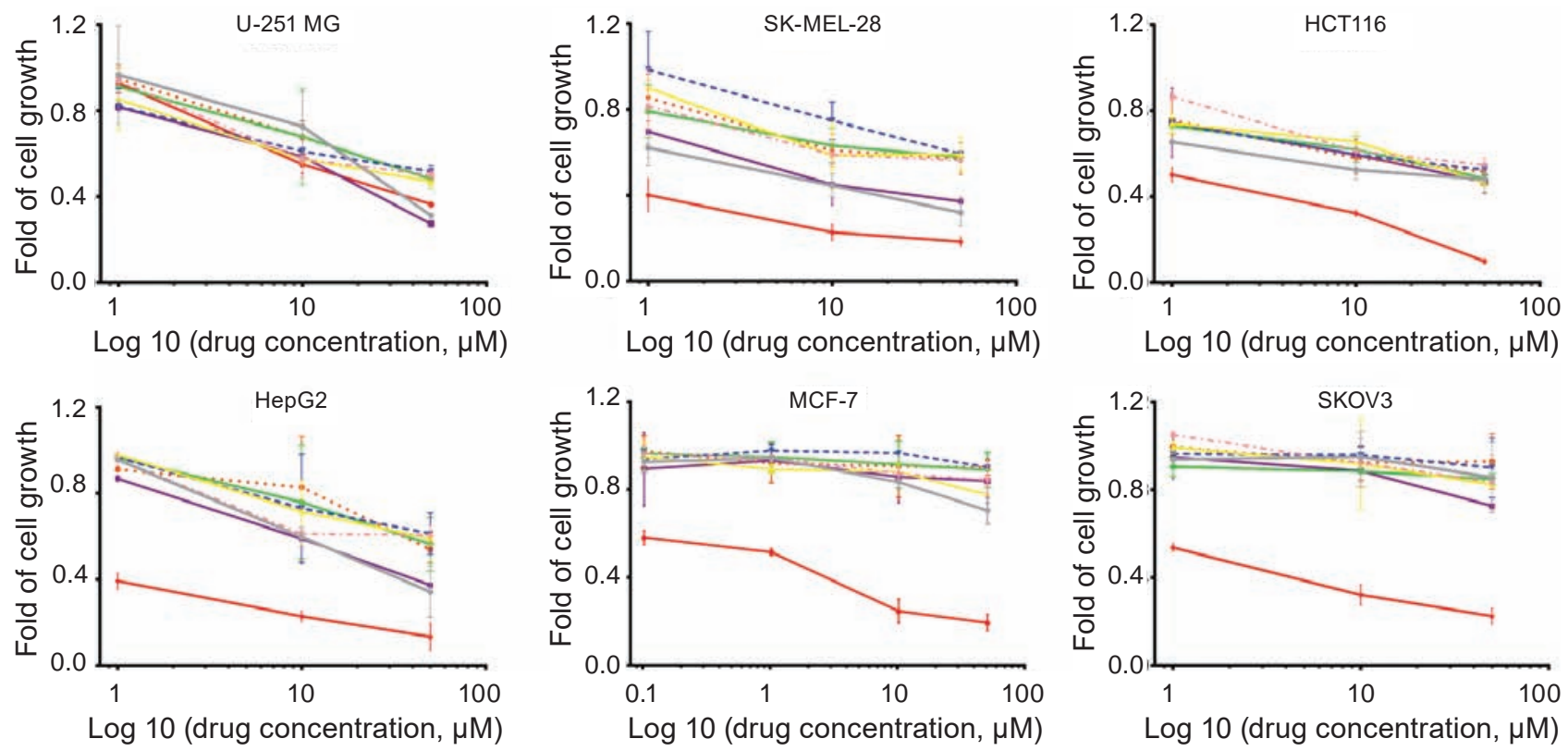

$-1=2$

$-3$

$\rightarrow-4 \leftarrow 5$

- 6

$-7 \quad-$ Dox

Fig. 2. The results of measuring the antiproliferative activity of seven pyrazolothiazolopyrimidines and Doxorubicin (Dox) towards human glioblastoma (U-251 MG), melanoma (SK-MEL-28), colon (HCT116), hepatocellular (HepG2), breast (MCF-7) and ovary (SKOV3) carcinoma tumor cell lines. Cell viability was examined using the MTT assay after $72 \mathrm{~h}$ of the compound exposure. Dox was used as a positive control.

MCF-7 and SKOV3 cells showed the highest cytotoxic effect of that agent, 1.38 and $2.6 \mu \mathrm{M}$, respectively.

Thus, compounds 2 and 7 were the most cytotoxic agents towards a majority of tumor cell lines. Compound $\mathbf{2}$ contains a trifluoromethyl group in its structure, while compound 7 does not have polar groups in its structure. Therefore, compound 7 possesses better solubility because of its lipophilicity due to the propyl group. The noted structural peculiarities might increase uptake of these compounds by the cell and provide their high activity $[14,16]$.

In order to evaluate a potential side effect of the seven pyrazolothiazolopyrimidine derivatives, we studied their toxicity towards non-tumor cells (Fig. 3, Table). The cytotoxicity of the pyrazolothiazolopyrimidine derivatives and Doxorubicin towards HEK293 cells in decreasing order are as follows: Doxorubicin $\left(\mathrm{IC}_{50}=5.1 \mu \mathrm{M}\right)>$ compound $\mathbf{1}\left(\mathrm{IC}_{50}=10.6 \mu \mathrm{M}\right)>\mathbf{6}\left(\mathrm{IC}_{50}=23.2 \mu \mathrm{M}\right)>\mathbf{4}$ $\left(\mathrm{IC}_{50}=25.6 \mu \mathrm{M}\right)>\mathbf{5}\left(\mathrm{IC}_{50}=26.3 \mu \mathrm{M}\right)>\mathbf{2}$ $\left(\mathrm{IC}_{50}=30.0 \mu \mathrm{M}\right)>7\left(\mathrm{IC}_{50}=33.2 \mu \mathrm{M}\right)>3$ $\left(\mathrm{IC}_{50}=34.6 \mu \mathrm{M}\right)($ Table). The toxicity of the studied compounds and Doxorubicin towards $\mathrm{HaCaT}$ cells in decreasing order are as follows: Doxorubicin $\left(\mathrm{IC}_{50}=1.7 \mu \mathrm{M}\right)>$ compound $\mathbf{6}\left(\mathrm{IC}_{50}=12.7 \mu \mathrm{M}\right)>\mathbf{5}$
$\left(\mathrm{IC}_{50}=13.6 \mu \mathrm{M}\right)>\mathbf{1}\left(\mathrm{IC}_{50}=16.3 \mu \mathrm{M}\right)>\mathbf{4}$ $\left(\mathrm{IC}_{50}=17.2 \mu \mathrm{M}\right)>2\left(\mathrm{IC}_{50}=17.4 \mu \mathrm{M}\right)>\mathbf{3}$ $\left(\mathrm{IC}_{50}=21.8 \mu \mathrm{M}\right)>7\left(\mathrm{IC}_{50}=29.5 \mu \mathrm{M}\right)$ (Table). Similar results were found for action of the pyrazolothiazolopyrimidines towards J774.2 cells: Doxorubicin $\left(\mathrm{IC}_{50}=2.28 \mu \mathrm{M}\right)>$ compound $\mathbf{1}\left(\mathrm{IC}_{50}=14.7 \mu \mathrm{M}\right)>\mathbf{6}$ $\left(\mathrm{IC}_{50}=17.2 \mu \mathrm{M}\right)>\mathbf{5}\left(\mathrm{IC}_{50}=20.3 \mu \mathrm{M}\right)>\mathbf{2}$ $\left(\mathrm{IC}_{50}=20.8 \mu \mathrm{M}\right)>3\left(\mathrm{IC}_{50}=21.3 \mu \mathrm{M}\right)>7$ $\left(\mathrm{IC}_{50}=22.7 \mu \mathrm{M}\right)>\mathbf{4}\left(\mathrm{IC}_{50}=22.5 \mu \mathrm{M}\right)$ (Table). Thus, the pyrazolothiazolopyrimidine derivatives were less toxic than Doxorubicin towards non-tumor human embryonic kidney HEK293 cells, human keratinocytes of the HaCaT line, and murine macrophages of the J774.2 line.

In summary, we have demonstrated that in vitro cytotoxicity of the pyrazolothiazolopyrimidine derivatives is tissue dependent. Leukemia K-562 and HL-60 cells were the most sensitive to action of the pyrazolothiazolopyrimidines. Compounds 2 and 7 demonstrated the most prominent effect towards leukemia cells. In addition, compound 2 showed approximately two times higher toxicity towards the multidrug resistant sub-line of human myeloid leukemia HL-60/ADR cells when compared with the action of Doxorubicin (Fig. 4). Toxicity of compounds 2 and 7 towards melanoma cells was approximately 

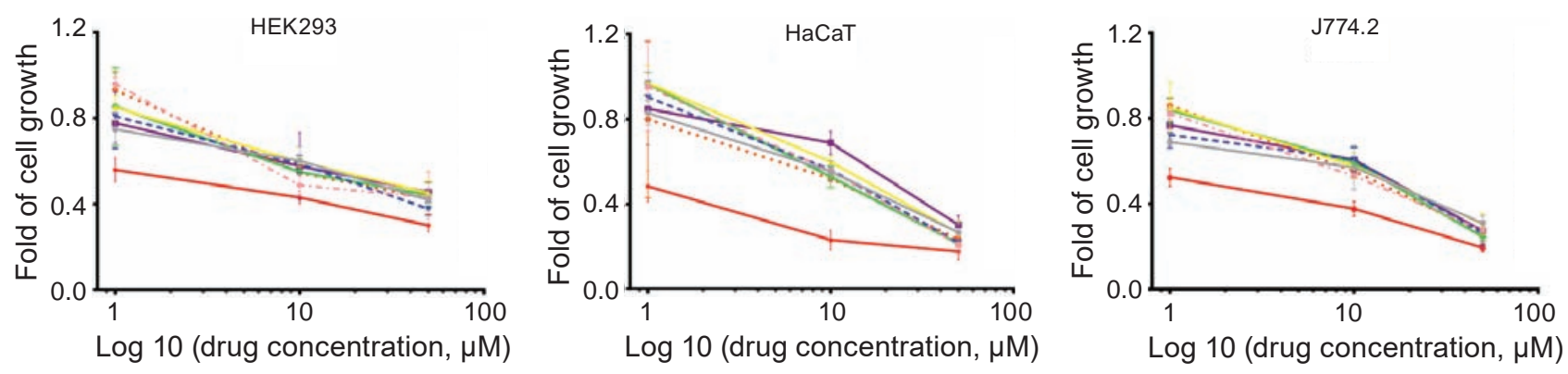

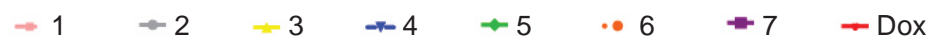

Fig. 3. The results of measuring the antiproliferative activity of seven pyrazolothiazolopyrimidines and Doxorubicin (Dox) towards different non-tumor cell lines (HEK293, HaCaT, J774.2). Cell viability was examined using the MTT assay after $72 \mathrm{~h}$ of the compound exposure. Dox was used as a positive control

10 times lower compared to the effect of Doxorubicin. Compounds 2 and 7 inhibited the viability of human glioblastoma U-251 MG cells, human colon carcinoma HCT116 cells, and human hepatocyte carcinoma HepG2 cells with values of $\mathrm{IC}_{50}$ under $21 \mu \mathrm{M}$, and possessed less toxicity compared with Doxorubicin. Human breast adenocarcinoma MCF7 cells and human ovarian carcinoma SKOV3 cells demonstrated the weakest sensitivity to the pyrazolothiazolopyrimidines. It should be mentioned that the pyrazolothiazolopyrimidine derivatives were less toxic than Doxorubicin towards non-tumor human embryonic kidney HEK293 cells, human keratinocytes of the HaCaT line, and murine macrophages of the J774.2 line. The next steps in our study will be focused on the potential mechanisms (induction of apoptosis, DNA single-strand breaks, effect on cell cycle distribution, intercalation into DNA molecule, genotoxic potential, binding with proteins) of the action of compounds 2 and 7 towards HL-60/ADR cells. We plan in vivo experiments on the action of pyrazolothiazolopyrimidine derivatives. The results of such experiments will provide information needed for starting clinical trials.

Conflicts of interest. The authors declare no conflict of interest.

\section{Acknowledgement}

This research was supported by the Ministry of Education and Science of Ukraine grant (registration number 0116U001533). The authors thank Dr. O. Stasyk (Institute of Cell Biology, National Academy of Sciences of Ukraine, Lviv, Ukraine) for donating human ovarian carcinoma SKOV3 cells. We thank Cedars - Sinai Medical Center's International Research and Innovation in Medicine Program, the Association for Regional Cooperation in the Fields of Health, Science and Technology (RECOOP HST Association) for their support of our organization as participating Cedars - Sinai Medical Center - RECOOP Research Centers (CRRC).

\section{References}

1. Kamba SA, Ismail M, Hussein-Al-Ali SH, Ibrahim TA, Zakaria ZA. In vitro delivery and controlled release of Doxorubicin for targeting osteosarcoma bone cancer. Molecules. 2013; 18(9): 10580-10598.

2. Rajak H, Veerasamy R, Kumar Gupta A, Dhar Kharya M, Mishra P. Synthesis, characterization and biological evaluation of some novel 2,5-disubstituted 1,3,4-thiadiazoles for their potential antimicrobial activity. Dig $J$ Nanomater Bios. 2009; 4(3): 443-451.

3. Singla P, Luxami V, Singh R, Tandon V, Paul K. Novel pyrazolo[3,4-d]pyrimidine with 4-(1H-benzimidazol-2-yl)-phenylamine as broad spectrum anticancer agents: Synthesis, cell based assay, topoisomerase inhibition, DNA intercalation and bovine serum albumin studies. Eur J Med Chem. 2017; 126: 24-35.

4. Nagender P, Malla Reddy G, Naresh Kumar R, Poornachandra Y, Ganesh Kumar C, Narsaiah B. Synthesis, cytotoxicity, antimicrobial and anti-biofilm activities of novel pyrazolo[3,4-b] pyridine and pyrimidine functionalized 1,2,3-triazole derivatives. Bioorg Med Chem Lett. 2014; 24(13): 2905-2908.

5. Hao $\mathrm{Y}, \mathrm{Xu} \mathrm{XP}, \mathrm{Chen} \mathrm{T}$, Zhao LL, Ji SJ. Multicomponent approaches to 8-carboxylnaphthyl-functionalized pyrazolo[3,4-b]pyridine derivatives. Org Biomol Chem. 2012; 10(4): 724-728. 

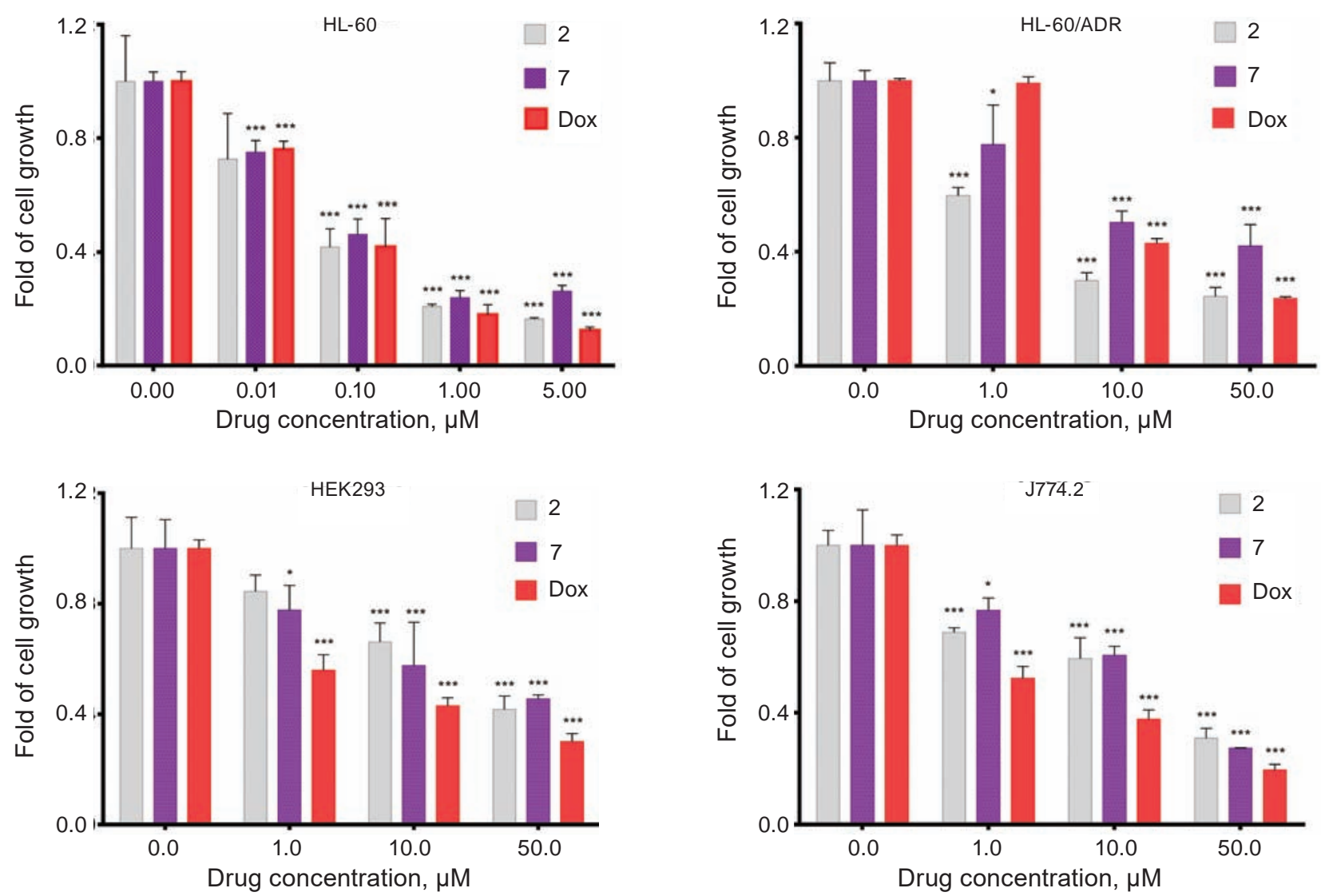

Fig. 4. The results of measuring in vitro cytotoxic effects of compounds 2 and 7 and Doxorubicin (Dox) towards human leukemia (HL-60, HL-60/ADR) and non-tumor embryonic kidney (HEK293) and macrophage (J774.2) cell lines. $* P \leq 0.05 ; * * P \leq 0.01 ; * * * P \leq 0.001$ (difference compared with the no treated control cells)

6. De Clercq E. Recent highlights in the development of new antiviral drugs. Curr Opin Microbiol. 2005; 8(5): 552-560.

7. Abdel-Aziz M, Abuo-Rahma Gel-D, Hassan AA. Synthesis of novel pyrazole derivatives and evaluation of their antidepressant and anticonvulsant activities. Eur J Med Chem. 2009; 44(9): 3480-3487.

8. de Mello H, Echevarria A, Bernardino AM, Canto-Cavalheiro M, Leon LL. Antileishmanial pyrazolopyridine derivatives: synthesis and structure-activity relationship analysis. J Med Chem. 2004; 47(22): 5427-5432.

9. Khobragade $\mathrm{CN}$, Bodade RG, Dawane BS, Konda SG, Khandare NT. Synthesis and biological activity of pyrazolo[3,4-d] thiazolo[3,2-a]pyrimidin-4-one derivatives: in silico approach. J Enzyme Inhib Med Chem. 2010; 25(5): 615-621.

10. Redenti S, Ciancetta A, Pastorin G, Cacciari B, Moro S, Spalluto G, Federico S. Pyrazolo[4,3-e] $[1,2,4]$ triazolo[1,5-c]pyrimidines and structu- rally simplified analogs. Chemistry and SAR profile as adenosine receptor antagonists. Curr Top Med Chem. 2016; 16(28): 3224-3257.

11. Baraldi PG, Saponaro G, Aghazadeh Tabrizi M, Baraldi S, Romagnoli R, Moorman AR, Varani K, Borea PA, Preti D. Pyrrolo- and pyrazolo-[3,4-e] $[1,2,4]$ triazolo[1,5-c]pyrimidines as adenosine receptor antagonists. Bioorg Med Chem. 2012; 20(2): 1046-1059.

12. Sidique S, Ardecky R, Su Y, Narisawa S, Brown B, Millán JL, Sergienko E, Cosford ND. Design and synthesis of pyrazole derivatives as potent and selective inhibitors of tissuenonspecific alkaline phosphatase (TNAP). Bioorg Med Chem Lett. 2009 Jan 1;19(1): 222225.

13. Song XJ, Shao Y, Dong XG. Microwaveassisted synthesis of some novel fluorinated pyrazolo[3,4-d]pyrimidine derivatives containing 1,3,4-thiadiazole as potential antitumor agents. Chin Chem Lett. 2011; 22(9): 1036-1038. 
14. Rahmouni A, Souiei S, Belkacem MA, Romdhane A, Bouajila J, Ben Jannet $\mathrm{H}$. Synthesis and biological evaluation of novel pyrazolopyrimidines derivatives as anticancer and anti-5-lipoxygenase agents. Bioorg Chem. 2016; 66: 160-168.

15. Kurumurthy C, Veeraswamy B, Sambasiva Rao P, Santhosh Kumar G, Shanthan Rao P, Loka Reddy V, Venkateswara Rao J, Narsaiah B. Synthesis of novel 1,2,3-triazole tagged pyrazolo[3,4-b]pyridine derivatives and their cytotoxic activity. Bioorg Med Chem Lett. 2014; 24(3): 746-749.

16. Kandeel MM, Refaat HM, Kassab AE, Shahin IG, Abdelghany TM. Synthesis, anticancer activity and effects on cell cycle profile and apoptosis of novel thieno[2,3-d]pyrimidine and thieno[3,2-e] triazolo[4,3-c]pyrimidine derivatives. Eur J Med Chem. 2015; 90: 620-632.

17. Nagender P, Naresh Kumar R, Malla Reddy G, Krishna Swaroop D, Poornachandra Y, Ganesh Kumar C, Narsaiah B. Synthesis of novel hydrazone and azole functionalized pyrazolo[3,4-b]pyridine derivatives as promising anticancer agents. Bioorg Med Chem Lett. 2016; 26(18): 4427-4432.

18. Shamroukh AH, Rashad AE, AbdelMegeid RE, Ali HS, Ali MM. Some pyrazole and pyrazolo[3,4-d]pyrimidine derivatives: synthesis and anticancer evaluation. Arch Pharm (Weinheim). 2014; 347(8): 559-565.

19. Ismail, Kuthati B, Thalari G, Bommarapu V, Mulakayala C, Chitta SK, Mulakayala N. Synthesis of novel spiro[pyrazolo[4,3-d] pyrimidinones and spiro[benzo[4,5] thieno[2,3-d]pyrimidine-2,3'-indoline]-2',4(3H)diones and their evaluation for anticancer activity. Bioorg Med Chem Lett. 2017; 27(6): 1446-1450.

20. Cicenas J, Kalyan K, Sorokinas A, Stankunas E, Levy J, Meskinyte I, Stankevicius V, Kaupinis A, Valius M. Roscovitine in cancer and other diseases. Ann Transl Med. 2015; 3(10): 135.

21. Tacar O, Sriamornsak P, Dass CR. Doxorubicin: an update on anticancer molecular action, toxicity and novel drug delivery systems. J Pharm Pharmacol. 2013; 65(2): 157-170.

22. Gratia S, Kay L, Potenza L, Seffouh A, NovelChaté V, Schnebelen C, Sestili P, Schlattner U, Tokarska-Schlattner M. Inhibition of AMPK signalling by doxorubicin: at the crossroads of the cardiac responses to energetic, oxidative, and genotoxic stress. Cardiovasc Res. 2012; 95(3): 290-299.

23. Liu J, Mao W, Ding B, Liang CS. ERKs/p53 signal transduction pathway is involved in doxorubicin-induced apoptosis in H9c2 cells and cardiomyocytes. Am J Physiol Heart Circ Physiol. 2008; 295(5): H1956-H1965.

24. Carvalho C, Santos RX, Cardoso S, Correia S, Oliveira PJ, Santos MS, Moreira PI. Doxorubicin: the good, the bad and the ugly effect. Curr Med Chem. 2009; 16(25): 3267-3285.

25. Finiuk NS, Hreniuh VP, Ostapiuk YuV, Matiychuk VS, Frolov DA, Obushak MD, Stoika RS, Babsky AM. Antineoplastic activity of novel thiazole derivatives. Biopolym Cell. 2017; 33(2): 135-146.

26. Senkiv J, Finiuk N, Kaminskyy D, Havrylyuk D, Wojtyra M, Kril I, Gzella A, Stoika R, Lesyk R. 5-Ene-4-thiazolidinones induce apoptosis in mammalian leukemia cells. Eur J Med Chem. 2016; 117: 33-46.

27. Thorn CF, Oshiro C, Marsh S, HernandezBoussard T, McLeod H, Klein TE, Altman RB. Doxorubicin pathways: pharmacodynamics and adverse effects. Pharmacogenet Genomics. 2011; 21(7): 440-446.

28. Yang F, Teves SS, Kemp CJ, Henikoff S. Doxorubicin, DNA torsion, and chromatin dynamics. Biochim Biophys Acta. 2014; 1845(1): 84-89.

29. Wu CH, Rastegar M, Gordon J, Safa AR. $\beta_{2}-$ microglobulin induces apoptosis in HL-60 human leukemia cell line and its multidrug resistant variants overexpressing MRP1 but lacking Bax or overexpressing P-glycoprotein. Oncogene. 2001; 20(48): 7006-7020.

Received 21.03.2018 